\title{
Dragons' den for photonics
}

\author{
A networking convention for photonics start-ups seeking funding will hold its fourth event in \\ October 2014 at Bordeaux, France.
}

Budding entrepreneurs looking to raise funds to launch or grow a start-up in the area of photonics should consider putting the dates 9-10 October 2014 into their diaries, because the fourth Invest in Photonics investment convention will be held in Bordeaux, France, over those two days. This networking event is designed to bring together venture capitalists, private investors, industry analysts and smallto-medium enterprises (SMEs) seeking funding. It was first held in 2008 and has been held on a biennial basis ever since. The organizers say that since its launch, Invest in Photonics has helped photonics companies raise more than US $\$ 119$ million (€87 million) in funding.

One of the event's unique features is an elevator pitch session, akin to the popular television series “Dragons' Den”. Following a screening process, 20 SMEs are selected to be given the opportunity to introduce their companies and technologies via threeminute presentations to a panel of potential investors and industry experts. Each presentation is followed by a two-minute question-and-answer session. The hope is that financiers will be sufficiently impressed to consider investing in some of the SMEs.

Those wishing to have the opportunity to give a pitch need to apply by 15 June 2014 (for an application form, see http://www.invest-in-photonics.com). Successful candidates will be coached by the French market analyst company Yole Développement regarding how they can optimize their investment presentations.

The 2014 event will focus on photonics technologies applicable to five market sectors: life sciences, consumer electronics, advanced manufacturing, the environment and energy, and aerospace and transport. Funding is typically used to further research and development, expand sales and marketing efforts or enter a new market. The Invest in Photonics organizing committee and selection panel will sign non-disclosure agreements with the selected companies.

Invest in Photonics is jointly organized by the Bordeaux Chamber of Commerce, the Aquitaine Laser Photonics and Applications (ALPhA) technology cluster and the research organization Commissariat à l'Energie Atomique (CEA),

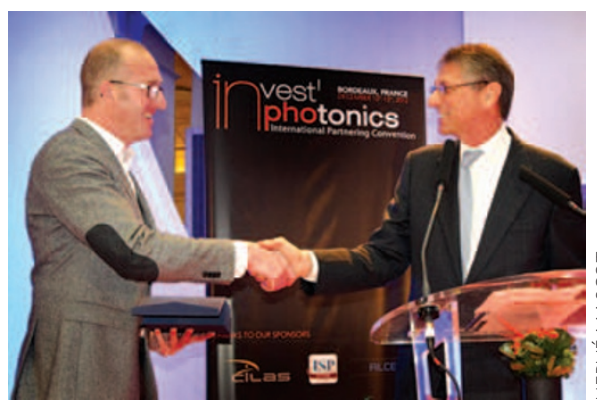

president at the aerospace firm Airbus), David Parker (managing partner of OPS Innovation) and Babak Parviz (a director at Google X and creator of Google Glass). One of the key driving forces behind Invest in Photonics is the entrepreneur and photonics industry veteran Giorgio Anania, the chairman of the event's program committee. Anania was formerly the chief executive officer of Bookham (now Oclaro), the UK optoelectronics firm developing optical integrated circuitry. He helped

which is funded by the French Government. According to Thierry Thevenin, a member of the organizing committee, Invest in Photonics originated from a local Bordeaux convention developed by the ALPhA cluster to support and finance the growth of the region's SMEs. "We spoke with the photonics unit of the European Commission and decided to internationalize the convention. In 2012, $40 \%$ of attendees came from abroad; the represented countries were Belgium, France, Germany, Ireland, the Netherlands, Spain, Switzerland, the UK and the USA."

Thevenin says that around 175-200 delegates are expected to attend the 2014 event, up from 150 in 2012. "Any SME from the photonics field and seeking funding can apply to give an elevator pitch. We will also provide a $€ 5,000$ cash prize to the winner [of the best-pitch award]." Previous winners include Michael Kramer from LED Linear (a German developer of lighting solutions based on light-emitting diodes (LEDs)) in 2010 and Philip Mathuis from Ovizio Imaging Systems (a Belgian spin-off that is commercializing research into digital holographic microscopy performed at the Free University of Brussels) in 2012. Other finalists in the 2012 event included Mach8 Lasers (a Dutch developer of mode-comb diode lasers), Holoxica (a UK threedimensional holography specialist) and a French firm Fibercryst (which makes laser gain modules and amplifiers based on single-crystal fibres).

In addition to the elevator pitches, there will be talks given by speakers from industry and the investment communities. Speakers at the 2014 event include Thibaud Le Seguillon (chief executive officer of Heliatek, the German maker of organic solar cells), Denis Chapuis (a vicesteer the company to a highly successful flotation on the London and New York stock exchanges in 2000. He is now the vice president of the European initiative Photonics 21 and chief executive officer of Aledia, a French development company of LED technology. Other members of the 14-strong program committee include Frank Lerch (managing director of OpTecBB, an innovation cluster in the Berlin region in Germany), Alastair Wilson (director of the UK's Photonics Knowledge Transfer Network), Carlos Lee (director general of the European Photonics Industry Association (EPIC)) and Vivek Tandon (founder and general partner of Aloe Private Equity).

"The venture capitalist world has taken a very abrupt turn towards software, mobile, the Internet and selected areas in the life sciences. Overall, this means a drastic reduction of investment in hardware. With fewer funds being invested in materials-science-based companies, it is increasingly more competitive and difficult for photonics companies to raise money," commented Anania.

"This means that photonics companies seeking to raise funds must use every opportunity to grab the attention of investors and pitch their projects in the most attractive way. Invest in Photonics provides the perfect venue for doing exactly that. It provides a panel of international investors, customized coaching and an enriched networking experience."

Invest in Photonics will be held on October 9-10 2014 at the Palais de la Bourse in Bordeaux, France. Those wishing to attend the event can register at the event's website. The fee to attend is $€ 350$. For more information, visit http://www.invest-in-photonics.com. 